\title{
REGIONÁLNÍ ROZVOJ A ROZVOJOVÁ POMOC NA PŘ́́KLADU VYBRANÉ ZEMĚ Z OBLASTI BALKÁNU - SRBSKO
}

REGIONAL DEVELOPMENT AND DEVELOPMENT ASSISTANCE ON
EXAMPLE SELECTED COUNTRY OF THE BALKAN - SERBIA

\section{BC. LENKA TOMŠÍKOVÁ}

\author{
DOC. ING. ARCH. VLAdimíra ŠILHÁNKOVÁ, PH.D. \\ \begin{tabular}{l|l}
$U$ Ustav regionálních a bezpečnostnich věd & Institute of Regional and Security Sciences
\end{tabular} \\ Fakulta ekonomicko-správní Faculty of Economics and Administration \\ Univerzita Pardubice University of Pardubice \\ $\triangle$ Studentská 84, 53210 Pardubice, Czech Republic \\ E-mail: tomsikova.L@seznam.cz,vladimira.silhankova@upce.cz
}

\begin{abstract}
Anotace
Tento článek se věnuje problematice regionálního rozvoje a rozvojové pomoci na konkrétním príkladu české rozvojové pomoci tzv. projektové zemi, a to konkrétně Srbsku. Článek se soustředi na hospodářský vývoj Srbska v kontextu regionálni rozvojové pomoci této balkánské zemi. Popisuje jednotlivé tematické oblasti pomoci a vybrané projekty, které zde Česká republika v rámci zahranični rozvojové spolupráce realizuje a pokouši se zhodnotit efektivnost poskytnuté pomoci.

\section{Klíčová slova}

regionální rozvoj, rozvojová pomoc, Srbsko, zahranični rozvojová spolupráce

\section{Annotation}

This paper deals with the issue of regional development and development assistance on a specific example of the Czech development assistance to the project country, specifically Serbia. The paper focuses on the economic development in Serbia in the context of regional development assistance to this Balkan country. Describes the individual thematic areas of development assistance and selected projects, which Czech Republic implements in the framework of international development cooperation and try to evaluate the effectiveness of the provided assistance.
\end{abstract}

\section{Key words}

regional development, development assistance, Serbia, international development cooperation

JEL classification: $X 12$

\section{Úvod}

Současný svět lze charakterizovat jako svět mnoha různorodostí a protikladů. Rozdíly různých povah spočívajících v odlišném množství hospodářského bohatství jednotlivců i zemí, dále v odlišné životní úrovni obyvatelstva a celkové kvalitě života, nebo také v množství dostupných zdrojů se ale objevovaly již v dávné minulosti. Mezi další důvody, kvůli kterým je možné, že je jedna země bohatší a druhá chudší, patří také odlišnost kultur a tradic, vnitřní geografické podmínky, politické zájmy, válečné konflikty a další. Jako hlavní zdroj tohoto nerovnoměrného stavu a uspořádání ve světě lze označit různorodé rozmístění př́rodních zdrojů. Pouze tam, kde jich bylo dostatek, mohlo docházet $\mathrm{k}$ intenzivnějšímu hospodářskému rozvoji. 
Současný nerovnoměrný vývoj pramení právě z předešlého vývoje společnosti. Tyto problémy poukazují na to, jaká existuje globální provázanost mezi rozvinutými a rozvojovými zeměmi. Motivací pro zlepšení situace v chudších zemích není jen solidarita mezi zeměmi, ale také snaha v dlouhodobém horizontu zlepšit situaci globální společnosti.

Proto vznikla zahraniční rozvojová spolupráce, která má pomoci rozvojovým zemím se zlepšením jejich současné hospodářské i sociální situace. Země ekonomicky vyspělé tak poskytují svou rozvojovou pomoc zemím, které mají hospodářské problémy. Aby rozvojová pomoc plnila svůj účel, je důležité umět ji efektivně využivat a vytěžit $\mathrm{z}$ ní pro rozvoj dané země maximum.

Cílem článku je zaměřit se na regionální rozvoj a mezinárodní rozvojovou pomoc České republiky a analyzovat konkrétní zahraniční rozvojovou spolupráci mezi Českou republikou a tzv. projektovou zemí západního Balkánu, konkrétně Srbskem.

Pro naplnění cíle článku byla jako základní výzkumná metoda využita zejména metoda sběru a analýzy dat a informací, které byly čerpány a dále zpracovány $\mathrm{z}$ dostupné odborné literatury a webových stránek. Ve druhé části práce šlo hlavně o jejich další zpracování induktivní metodou vč. závěrečné syntézy.

\section{Regionální rozvoj a rozvojová pomoc České republiky}

Rozvojová pomoc je důležitou součástí zahraniční politiky ČR, která touto činností přispívá ke splnění svých zahraničně-politických cílů a měla by vést $\mathrm{k}$ neustálému zlepšování zahraničních vztahů se všemi partnerskými zeměmi.

Rozvojová pomoc je způsob, jak vyspělé státy světa, včetně České republiky, pomáhají řešit problematickou situaci $\mathrm{v}$ zemích rozvojových a přispívají $\mathrm{k}$ jejich ekonomickému rozvoji. Základními formami zahraniční spolupráce je pomoc humanitární, která má krátkodobý charakter a klade si za cíl zmírnění útrap lidí, ochranu životů a pomoc lidem zasaženým humanitární krizí, a dále pomoc rozvojová, která z dlouhodobého hlediska zasahuje do oblastí sociálních, ekonomických, do problematiky životního prostředí a procesu formování státní správy.

Co se týká celosvětových dokumentů, nejvýznamnější strategii představují tzv. Rozvojové cíle tisíciletí (MDG's). Jedná se o program OSN, který se na základě měřitelných cílů v oblasti rozvoje zaměřuje na boj proti celosvětové chudobě. Bylo definováno osm základních cílů: Odstranit extrémní chudobu a hlad, Dosáhnout základního vzdělání pro všechny, Prosazovat rovnost pohlaví - mužů a žen a posílit roli žen ve společnosti, Snížit dětskou úmrtnost, Zlepšit zdraví matek, Bojovat s HIV/AIDS, malárií a dalšími nemocemi, Zajistit udržitelný stav životního prostředí a Budovat světové partnerství pro rozvoj. Všechny tyto cíle by měly být splněny do roku 2015.

ČR poskytuje zahraniční pomoc již od roku 1989, a to formou dvoustranné, trilaterální nebo mnohostranné spolupráce s vybranými rozvojovými zeměmi. Oficiální pomoc ČR je upravena několika strategickými dokumenty, kterými jsou zejména zákon č. 151/2010 Sb., o zahraniční rozvojové spolupráci a humanitární pomoci a Koncepce zahraniční rozvojové spolupráce ČR aktuálně na období 2010 - 2017.

Rozvojovou spoluprací se v ČR zabývá velké množství státních i nestátních aktérů. Nejvyšším výkonným orgánem je vláda ČR, která dále spolupracuje s Ministerstvem zahraničních věcí a dalšími institucemi jako jsou sektorová ministerstva, Rada pro zahraniční rozvojovou spolupráci, Česká rozvojová agentura, soukromé firmy, akademický sektor, nevládní neziskové a státní a příspěvkové organizace.

Důležité je si v této souvislosti položit otázku, proč Česká republika rozvojovou pomoc poskytuje, proč právě Srbsku a zda je tato rozvojová pomoc účinná či ne? 


\section{Rozvojová pomoc České republiky v Srbsku}

Srbská republika nepatří zrovna k nejchudším zemím světa a není proto přímo závislá na rozvojové spolupráci jako některé nejchudší země světa. Přesto se Srbsko stalo součástí skupiny států, do nichž Česká republika směřuje svoji rozvojovou pomoc. ČR definovala svi̊j aktuální Koncept zahraniční rozvojové spolupráce v roce 2010, kde Srbsko zařadila mezi tzv. programové země, tj. mezi země, kterým poskytuje zahraniční rozvojovou pomoc. Důvodem pro to jsou zejména významné historické vazby Srbska a České republiky. ČR a Srbsko dlouhodobě udržují přátelské a partnerské vztahy, které se začaly nejvíce rozvíjet v 19. století a velkého významu dosáhly v období mezi I. a II. světovou válkou. Nejdůležitějším výsledkem i oceněním dosavadního pozitivního rozvoje Srbska, a zároveň impulsem do budoucnosti, je udělení statusu kandidátské země EU, oficiálně potvrzené v březnu 2012. Tento impuls vedl ke změně v př́ístupu poskytování pomoci.

Hlavní vizí ČR pro zahraniční pomoc v Srbsku v letech 2010 - 2017 již není čistě rozvojová spolupráce, ale předávání technického know-how, zkušeností s procesem ekonomické transformace a spolupráce zaměřená na asistenci před vstupem do EU. Mimo toto zaměření, které je spojeno se snahou Srbska vstoupit do EU, je pomoc směřvána cíleně do několika sektorů. Pro aktuální období je to pět sektorů, které se ukázaly jako nejpotřebnější, a to sektor dopravy, sektor výroby a dodávky energie, sektor obchodu, sektor zásobování vodou a sanitace a sektor zdravotnictví.

Z hlediska poskytnutého objemu rozvojové pomoci od České republiky se Srbsko jako př́jemce řadí na páté místo mezi všemi tzv. prioritními zeměmi a na místo první mezi tzv. zeměmi projektovými. ${ }^{1}$

Tab. 1: Objem bilaterální ZRS ČR v roce 2011 (v mil. Kč)

\begin{tabular}{|l|c|}
\hline \multicolumn{1}{|c|}{ Země } & Objem v mil. Kč \\
\hline 1. Afghánistán & 201 \\
\hline 2. Mongolsko & 76 \\
\hline 3. Moldavsko & 76 \\
\hline 4. Bosna a Hercegovina & 61 \\
\hline 5. Srbsko & $\mathbf{5 6}$ \\
\hline 6. Etiopie & 51 \\
\hline 7. Gruzie & 35 \\
\hline ... & $\ldots$ \\
\hline
\end{tabular}

Zdroj: vlastní zpracování dle údajů z MZV ČR

Následující tabulka ukazuje celkový objem poskytnuté zahraniční rozvojové spolupráce ČR od roku 2007. Nejvíce prostředků bylo poskytnuto v roce 2008, v dalších letech objem prostředků klesal. Je též stanoven výhled rozvojové pomoci pro léta 2013 a 2014, který je už poměrně nízký a činí 22 mld. Kč.

Tab. 2: Objem poskytnuté ZRS ČR Srbsku v letech 2007- 2014

\begin{tabular}{|c|c|c|c|c|c|c|c|c|}
\hline Rok & 2007 & 2008 & 2009 & 2010 & 2011 & 2012 & 2013 & 2014 \\
\hline Rozpočet & 66,527 & 132,87 & 71,36 & 68,21 & 55,736 & 34,878 & $22 *$ & $22^{*}$ \\
\hline
\end{tabular}

* výhled ZRS ČR z roku 2011 na léta 2013 a 2014

Zdroj: vlastní zpracování dle údajů z MZV ČR

Projekty zahraniční rozvojové spolupráce v rámci pomoci ČR Srbsku probíhají v letech 2010 - 2014 v pěti výše popsaných sektorech, přičemž v roce 2013 probíhá realizace tř́ projektů - projekt

\footnotetext{
${ }^{1}$ Prioritní země - Koncepce zahraniční rozvojové spolupráce ČR na období 2010 - 2017 určila jako prioritní země Afghánistán, Bosnu a Hercegovinu, Etiopii, Moldavsko a Mongolsko. Jedná se o země, kde je zahraniční rozvojová pomoc nutná a je založena na dvoustranném programu spolupráce.

Projektové země - země, kde je podle Koncepce zahraniční rozvojové spolupráce ČR na období 2010 - 2017 zahraniční rozvojová pomoc rovněž žádoucí, z objektivních důvodů však nemůže být založena jen na dvoustranném programu spolupráce. Patří sem Gruzie, Kambodža, Kosovo, Palestinská autonomní území a Srbsko.
} 
v sektoru výroby a dodávky energie „Zvýšení energetické efektivnosti při vytápění nemocnice ve městě Valjevo“, v sektoru obchodu a dalších služeb projekt „Podpora výroby sýrů v oblasti Peštěr/Šandžak“ a v sektoru zásobování vodou a sanitace projekt „Výstavba kanalizační sítě v obci Kruščica“" (ostatní projekty byly již do roku 2012 ukončen).

Graf 1: Přehled bilaterálních projektů ČR v Srbsku dle sektorů v CZK (2010 - 2014)

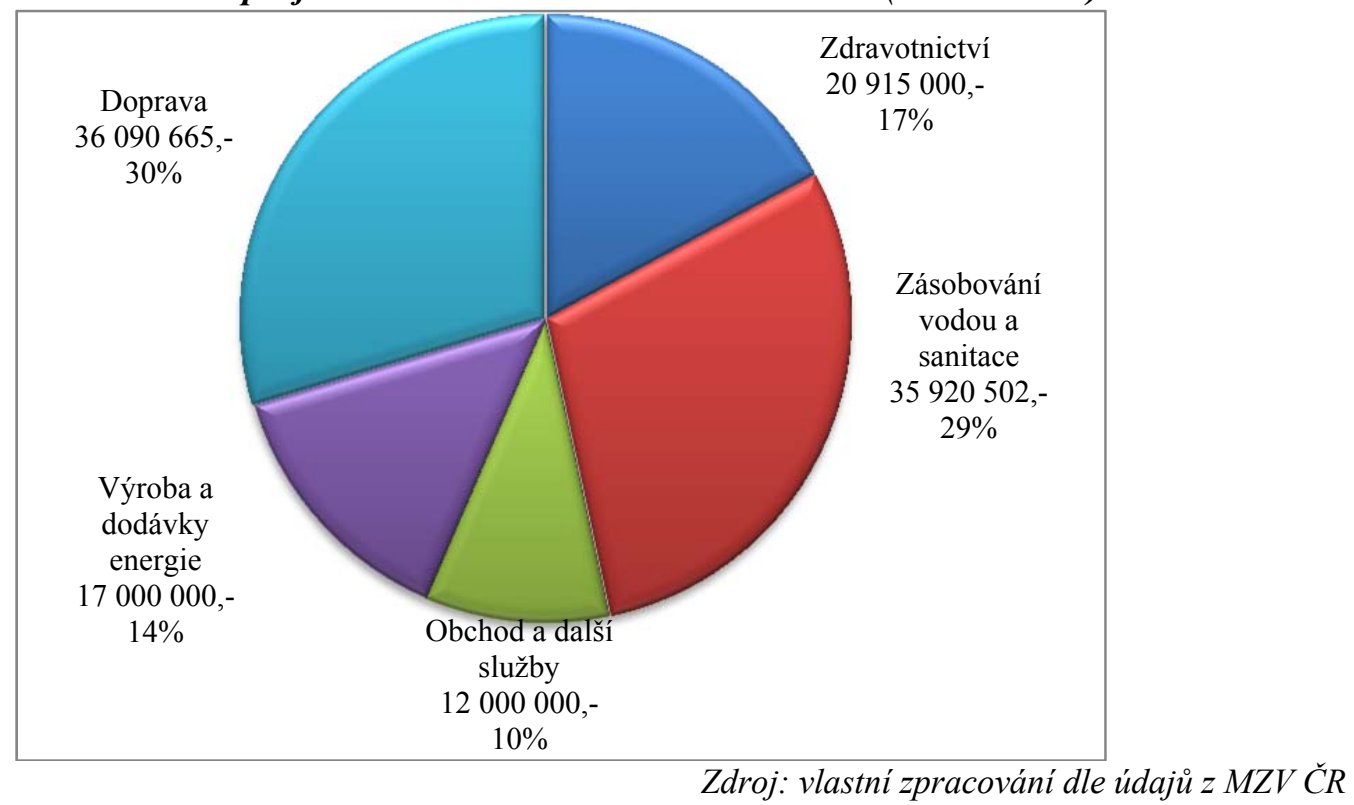

Jak lze vidět na grafu, největší podíl $(30 \%$ ) z celkové bilaterální pomoci ČR Srbsku za období 2010 2014, tvoří sektor dopravy. Druhým sektorem je (s jen o jedno procento nižším podílem, tedy s $29 \%$ ) sektor zásobování vodou a sanitace. Následují sektory zdravotnictví (17\%), výroba a dodávky energií $(14 \%)$ a poslední obchod a další služby $(10 \%)$.

\section{Zhodnocení zahraniční rozvojové spolupráce ČR v Srbsku}

Česká republika se v 90. letech 20. století potýkala s velmi obdobnými hospodářskými problémy, se kterými se v současnosti potýká Srbsko. Jedná se zejména o problémy spojené s transformací plánovaného hospodářství k ekonomice tržní a také s přechodem od komunistického režimu $\mathrm{k}$ demokratické vládě. Hlavně díky těmto zkušenostem z minulosti může zahraniční rozvojová pomoc České republiky v Srbsku dosahovat efektivnějších výsledků a může být o to přínosnější než intervence ze strany států a institucí, které tuto zkušenost nemají.

Česká zahraniční spolupráce byla pro aktuální období rozdělena do několika sektorů, kam byla pomoc směřována. Mezi nejdůležitější oblasti z hlediska potřeby pro kvalitní hospodářský, resp. regionální rozvoj patří zajištění dopravní infrastruktury, v jejichž obnově, modernizaci a výstavbě lze spatřovat pozitivní výsledky. Obdobná situace je i v technické infrastruktuře.

V oblasti energetiky, výroby a dodávky energií je př́nosné, že se ČR během své pomoci snažila realizovat projekty, které byly zaměřeny na využití obnovitelných zdrojů energií a na zdokonalení a modernizaci stávajících zařízení a postupů. Pozitivně lze také hodnotit rozvoj průmyslu, obchodu a služeb, čímž je možné podpořit nové pracovní prŕíležitosti, a tím napomoci, aby se v Srbsku snížila v současné době velmi vysoká nezaměstnanost, která v roce 2012 dosáhla až 26 \% (BusinessInfo.cz, 2013).

Př́ínosnou spolupráci ovšem Česká republika nepřináší jen vtěchto sektorech, ale ve všech poskytnutých projektech. Větší pozornost by se však v současné době měla věnovat snaze Srbska o vstup do EU. Stejně tak jako transformaci na standardně fungující demokracii, tak i vstup do EU má 
ČR v nedávné paměti, a proto by měla ve svých konkrétních projektech směřovat větší pozornost právě do této oblasti.

Zahraniční rozvojovou pomoc lze rozhodně hodnotit jako pozitivní, efektivní a př́nosnou pro další vývoj Srbska.

\section{Celkové zhodnocení rozvojové spolupráce v Srbsku}

Vývoj Srbska lze nejlépe zobrazit na několika ukazatelích. Jedná se o hrubý domácí produkt (HDP), hrubý národní produkt (HNP) a index lidského rozvoje (HDI). Pokud dochází k pozitivnímu vývoji země, měly by hodnoty všech těchto ukazatelů stoupat, naproti tomu hodnota objemu prrijímané pomoci by $\mathrm{k}$ tomu měla neprímo úměrně klesat.

Hrubý domácí produkt (HDP) je makroekonomický ukazatel, který stanovuje celkovou peněžní hodnotu statků a služeb vytvořených za dané období na území jednoho státu. Je to klíčový ukazatel vývoje národního hospodářství a měří výkonnost ekonomiky. Na následujícím obrázku lze vidět vývoj hodnoty HDP v Srbsku v letech 2003 - 2011:

Graf 2: Vývoj hrubého domácího produktu (HDP) v Srbsku v USD (2003 - 2012)

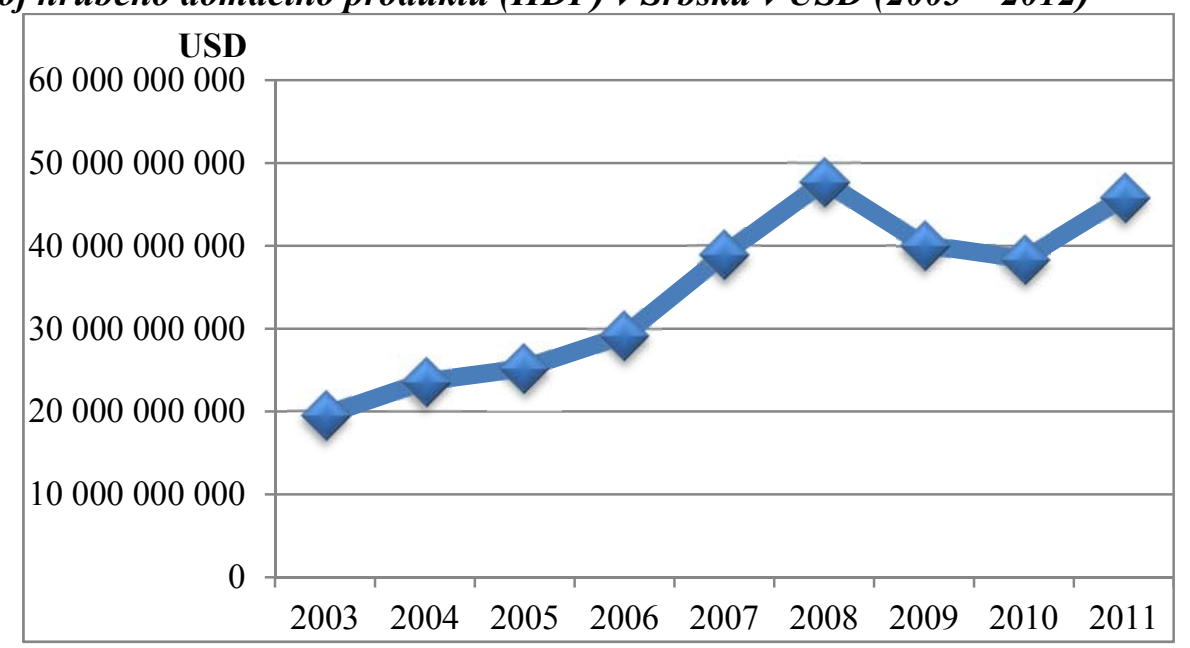

Zdroj: vlastní zpracování dle BusinessInfo.cz a údajů ze Srbské národní banky

Hrubý národní produkt (HNP, v angličtině GNP, nově i GNI - hrubý národní př́ijem) je makroekonomický údaj vyjadřující celkovou peněžní hodnotu statků a služeb vytvořených za dané období (což většinou bývá jeden rok), občany daného státu, bez ohledu na to, zda je to na území tohoto státu, či na území jiného státu, tedy v cizině. Aby byla výše HNP porovnatelná mezi jednotlivými zeměmi, přepočítává se na jednoho obyvatele. Následně lze podle jeho zvyšujícího se nebo snižujícího se trendu posoudit a vyhodnotit jaké je současné tempo růstu dané ekonomiky. 
Graf 3: Vývoj hrubého národního produktu (HNP) v Srbsku v USD (2003 - 2011)

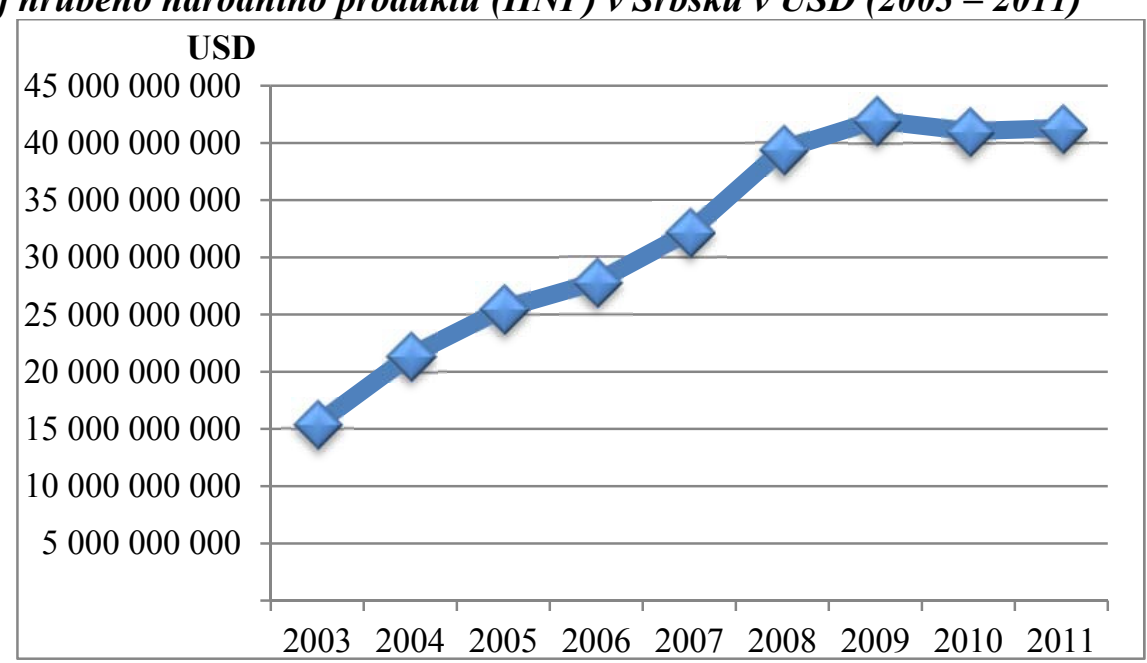

Zdroj: vlastní zpracování dle údajů The World Bank

Graf 4: Vývoj HNP na hlavu v Srbsku a rozvojových zemích Evropy a Střední Asie (20003 - 2011)

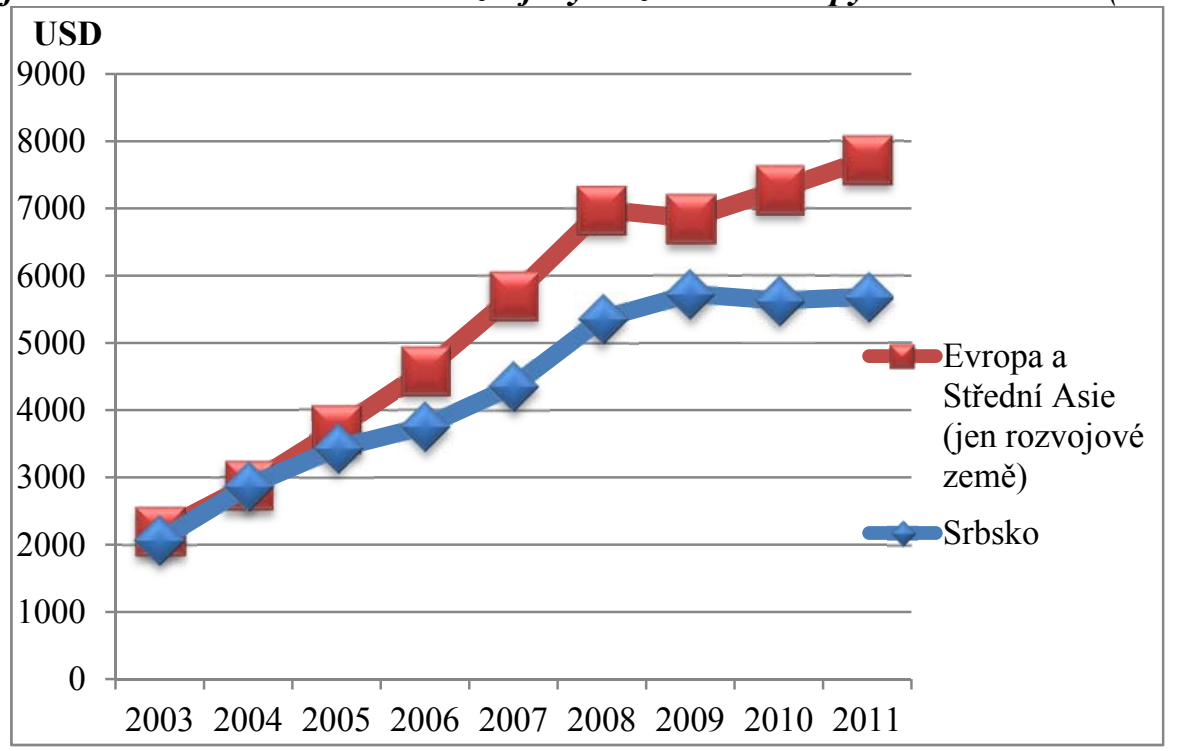

Zdroj: vlastní zpracováni dle údajů The World Bank

HNP Srbska měl v roce 2011 hodnotu 41,3 mld. USD, což ho řadí na 72. místo ve světovém žebříčku (pro srovnání nejvyšší HNP má USA, je to 15,1 bilionu USD, s velkým odstupem následuje Č́na 6,6 bilionu USD a Japonsko 5,7 bilionu USD. HNP ČR dosáhlo v roce 2011 hodnoty 196,3 mld. USD a ČR tak dosáhla na 44. místo v celosvětovém žebříčku). Na grafu 3 lze opět vidět pozitivní vývoj ve stoupajícím trendu (od roku 2009 do současnosti se udržuje zhruba ve stejné výši, což je s ohledem na globální hospodářskou krizi pozitivní výsledek).

Vývoj HNP na hlavu je zobrazen grafem 4 spolu s porovnáním HNP rozvojových zemí Evropy a Střední Asie. Vývoj Srbska je stejný jako na grafu předchozím, průměrný vývoj v ostatních rozvojových zemích Evropy a Střední Asie je ale rychlejší.

Index lidského rozvoje (Human Development Index - zkratka HDI) je ukazatel, který OSN zveřejňuje ve své každoroční zprávě. Používá se pro měření kvality lidského života a hodnotí zdravotní stav obyvatel, vzdělanost a př́ijmy. 
Podle údajů Rozvojového programu OSN se ČR nachází na 28. místě ze 187 zemí světa s hodnotou HDI 0,873. Na 1. místě se umístilo Norsko s HDI 0,943 a na posledním Demokratická republika Kongo s HDI dosahující pouze 0,286. Srbsko se nachází na 64. místě s hodnotou 0,769. Jednotlivé měřené složky jsou znázorněny na následujícím grafu:

Graf 5: HDI Srbska v roce 2011

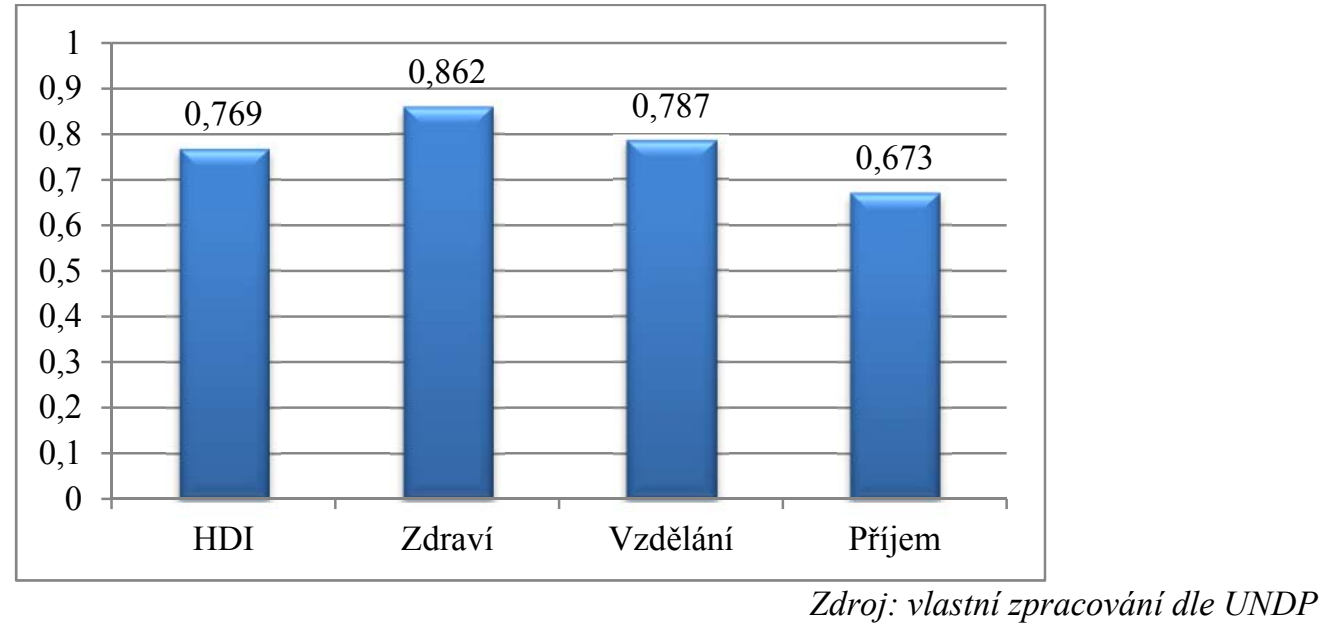

Graf 6: Vývoj HDI v Srbsku, Evropě a Střední Asii a ve světě v letech 1980-2012

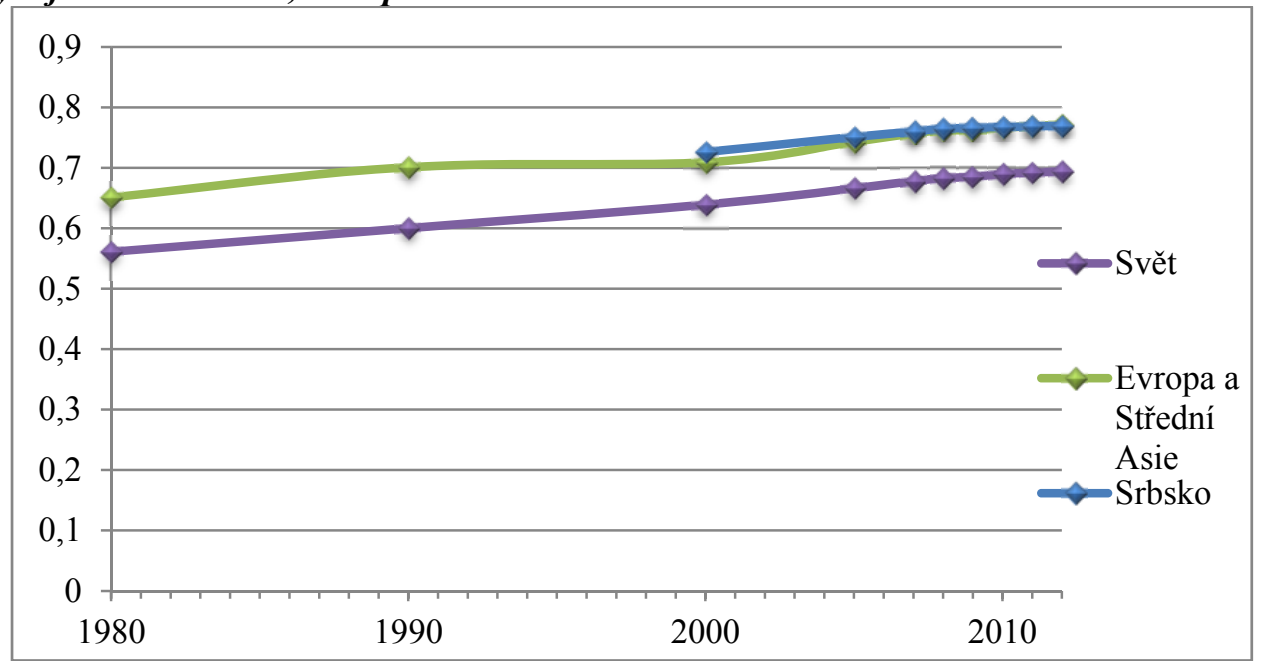

Zdroj: vlastní zpracování dle UNDP

\section{Závěr}

Zahraniční rozvojová pomoc má na Srbsko pozitivní vliv a zdá se být efektivní v ní nadále pokračovat, dokud Srbsko nesplní hospodářské podmínky a nebude způsobilé pro vstup do Evropské unie. Další hospodářský růst musí být tažen podnikáním a investováním do rozvoje strategických sektorů národního hospodářství. V zemi je ale zároveň třeba mít dostatečně chráněná vlastnická práva, odstranit překážky v podnikání a korupci. Další rozvojová pomoc bude tedy dostatečně efektivní pouze $\mathrm{v}$ tom př́ipadě, pokud se Srbsko zaměří na tyto specifické oblasti a bude klást důraz na odstranění dosavadních bariér a bude se intenzivně snažit o další pokrok.

\section{Literatura}

[1] ADAMCOVÁ, L., NĚMEČKOVÁ, T. a kol. Rozvojová ekonomika. Praha: Oeconomica, 2009. ISBN 978-80-245-1515-1. 
[2] Businessinfo.cz: Srbsko: ekonomická charakteristika země [online]. 2013 [cit. 2013-03-23]. Dostupné z: [http://www.businessinfo.cz/cs/clanky/srbsko-ekonomicka-charakteristika-zeme18540.html].

[3] Česká republika pomáhá [online]. 2012 [cit. 2013-03-17]. Dostupné z: [http://www.mzv.cz/file/876652/Ceska_Republika_Pomaha.pdf].

[4] Česká rozvojová agentura: Rozvojová spolupráce ČC (ZRS) [online]. 2009 [cit. 2013-02-18]. Dostupné $\quad \mathrm{z}$ : $\quad[\mathrm{http}: / /$ www.czda.cz/rozvojova-spoluprace/rozvojove-cile-tisicileti.htmace/rozvojova-spoluprace-cr-zrs.htm].

[5] HORKÝ, O. Česká rozvojová spolupráce: Diskursy, praktiky, rozpory. Praha: Sociologické nakladatelství (Slon), 2010. ISBN 978-80-7419-040-7.

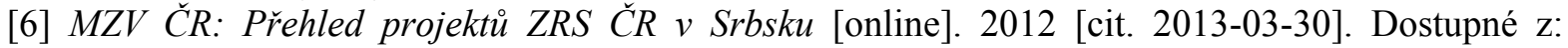
[http://www.mzv.cz/jnp/cz/zahranicni_vztahy/rozvojova_spoluprace/dvoustranna_zrs_cr/projekto ve_zeme/srbsko/prehled_projektu_zrs_cr_v_srbsku.html].

[7] Oficiální webová stránka vlády RS [online]. 2004-2013 [cit. 2013-03-23]. Dostupné z: [http://www.srbija.gov.rs/pages/intro.php?id=35].

[8] Rozvojovka: Zahraniční rozvojová spolupráce ČCR v roce 2011 [online]. 2011 [cit. 2013-03-17]. Dostupné z: [http://www.fors.cz/wp-content/uploads/2012/12/AW-brief-final.pdf/rozvojovaspoluprace-cr-prioritni-zeme-1286.html\#!].

[9] TOMŠÍKOVÁ, L. Regionální rozvoj a rozvojová pomoc na př́kladu vybrané zemé z oblasti Balkánu - Srbsko. [Diplomová práce] Pardubice: Univerzita Pardubice, 2013.

[10] UNDP [online]. 2013 [cit. 2013-04-20]. Dostupné $<$ http://hdrstats.undp.org/en/countries/profiles/SRB.html $>$.

Př́spěvek byl zpracován s podporou IGA Univerzity Pardubice v souvislosti s řešením projektu č. SGFES01/2013. 